Supporting Information

\title{
Preparation and Properties of Phosphaethynes Bearing Bulky Aryl Groups with Electron-donating Substituents at the para-Position
}

\author{
Kozo Toyota, Subaru Kawasaki, and Masaaki Yoshifuji* \\ Department of Chemistry, Graduate School of Science, Tohoku University, Aoba, \\ Sendai 980-8578, Japan \\ yoshifj@mail.tains.tohoku.ac.jp
}

\section{CONTENTS}

1. Preparation of 4-bromo-3,5-xylidine S3

2. Preparation of 2,5-dibromo-1,3-dimethylbenzene (3) S3

3. Crystal data for 2-[2,6-di-t-butyl-4-(dimethylamino)phenyl]-1-phosphaethyne (2c) S3

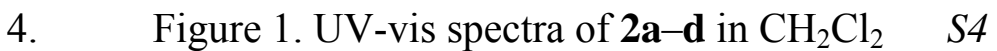

5. Figure 2. UV spectra of $p$-substituted phenylacetylenes and benzonitriles in $\mathrm{CH}_{2} \mathrm{Cl}_{2} \quad S 5$

6. Figure $3 .{ }^{13} \mathrm{C}\left\{{ }^{1} \mathrm{H}\right\}$ NMR $\left(100 \mathrm{MHz}, \mathrm{CDCl}_{3}\right)$ spectrum of 2,5-dibromo-1,3-di-tbutylbenzene (1e) S5

7. Figure $4 .{ }^{13} \mathrm{C}\left\{{ }^{1} \mathrm{H}\right\}$ NMR $\left(100 \mathrm{MHz}, \mathrm{CDCl}_{3}\right)$ spectrum of (4-bromo-3,5-di-t-butylphenyl)(diphenylmethylene)amine (1f) S6

8. Figure 5. ${ }^{13} \mathrm{C}\left\{{ }^{1} \mathrm{H}\right\}$ NMR (100 MHz, $\left.\mathrm{CDCl}_{3}\right)$ spectrum of (2,6-di-t-butylphenyl)-1phosphaethyne (2a) S6 
9. Figure $6 .{ }^{13} \mathrm{C}\left\{{ }^{1} \mathrm{H}\right\}$ NMR $\left(100 \mathrm{MHz}, \mathrm{CDCl}_{3}\right)$ spectrum of (2,6-di-t-butyl-4-methoxyphenyl)1-phosphaethyne (2b) S7

10. Figure 7. ${ }^{13} \mathrm{C}\left\{{ }^{1} \mathrm{H}\right\}$ NMR (100 MHz, $\left.\mathrm{CDCl}_{3}\right)$ spectrum of [2,6-di-t-butyl-4-(dimethylamino)phenyl]-1-phosphaethyne (2c) S7

11. Figure $8 .{ }^{13} \mathrm{C}\left\{{ }^{1} \mathrm{H}\right\}$ NMR (100 MHz, $\left.\mathrm{CDCl}_{3}\right)$ spectrum of 2,5-dibromo-1,3-bis(bromomethyl)benzene (4) S8

12. Figure 9. ${ }^{13} \mathrm{C}\left\{{ }^{1} \mathrm{H}\right\} \mathrm{NMR}\left(100 \mathrm{MHz}, \mathrm{CDCl}_{3}\right)$ spectrum of 2,5-dibromo-1,3-bis(cyanomethyl)benzene (5) $\quad S 8$

13. Figure 10. ${ }^{13} \mathrm{C}\left\{{ }^{1} \mathrm{H}\right\}$ NMR (100 MHz, $\left.\mathrm{CDCl}_{3}\right)$ spectrum of 2,5-dibromo-1,3-bis(1-cyano-1methylethyl)benzene (6) S9

14. Figure $11 .{ }^{13} \mathrm{C}\left\{{ }^{1} \mathrm{H}\right\} \mathrm{NMR}\left(100 \mathrm{MHz}, \mathrm{CDCl}_{3}\right)$ spectrum of (dibromomethylene)(2,6-di-t-butylphenyl)phosphine (9a) S9

15. Figure $12 .{ }^{13} \mathrm{C}\left\{{ }^{1} \mathrm{H}\right\}$ NMR $\left(100 \mathrm{MHz}, \mathrm{CDCl}_{3}\right)$ spectrum of (dibromomethylene)(2,6-di-t-butyl4-methoxyphenyl)phosphine (9b) S10 
Preparation of 4-bromo-3,5-xylidine. To a solution of 3,5-xylidine (50 g, $0.41 \mathrm{~mol})$ in $\mathrm{CHCl}_{3}$ $(500 \mathrm{~mL})$ was added $90 \mathrm{~mL}(0.64 \mathrm{~mol})$ of $\mathrm{NEt}_{3} . \quad$ Acetic anhydride $(20 \mathrm{ml} \times 3$ times, total $0.64 \mathrm{~mol})$ was then added at $0{ }^{\circ} \mathrm{C}$, and the mixture was warmed to room temperature. After being stirred for 4 h, the mixture was washed with $1 \mathrm{M}$ hydrochloric acid, saturated aq. $\mathrm{NaHCO}_{3}$, and brine. The organic layer was dried over $\mathrm{MgSO}_{4}$, and concentrated. The residue was dissolved in acetonitrile (1.5 L) and NBS (71 g, $0.40 \mathrm{~mol})$ was slowly added at room temperature. After $12 \mathrm{~h}$-stirring, precipitates were collected and the solvent was removed under reduced pressure. The residue and the precipitates were combined, and to this mixture were added EtOH $(300 \mathrm{~mL})$, water $(400 \mathrm{~mL})$, and conc. hydrochloric acid $(125 \mathrm{~mL})$. The resulting mixture was refluxed for $6 \mathrm{~h}$. After cooling to room temperature, $\mathrm{NaOH}$ was added until $\mathrm{pH}$ of the solution became higher than 12 . The precipitates were collected and dried to give $79.9 \mathrm{~g}$ (98\% yield) of 4-bromo-3,5-xylidine.

Preparation of 2,5-dibromo-1,3-dimethylbenzene (3). $\quad \mathrm{NaNO}_{2}(17.6 \mathrm{~g}, 0.26 \mathrm{~mol})$ was added to conc. sulfuric acid $(130 \mathrm{~mL})$ at $0{ }^{\circ} \mathrm{C}$. To the resulting mixture was added acetic acid $(100 \mathrm{~mL})$, and then $2(17 \mathrm{~g} \mathrm{x} 3$ times, total $0.26 \mathrm{~mol})$ portionwise. The mixture was stirred at $0-10{ }^{\circ} \mathrm{C}$ for $1 \mathrm{~h}$ and $100 \mathrm{~mL}$ of acetic acid was added to the mixture. Then the resulting solution was poured into a mixture of $\mathrm{CuBr}(45 \mathrm{~g}, 0.31 \mathrm{~mol})$ and $48 \%$ hydrobromic acid $(130 \mathrm{~mL})$. The resulting mixture was allowed to warm to $70{ }^{\circ} \mathrm{C}$ and vigorously stirred for $2 \mathrm{~h}$. The solution was diluted with hexane and water. The organic layer was washed with brine, dried over $\mathrm{MgSO}_{4}$, and concentrated. Column chromatography $\left(\mathrm{SiO}_{2} /\right.$ hexane) of the residue provided $25.4 \mathrm{~g}$ (38\% yield) of 3 .

\section{Crystal data for 2-[2,6-di-t-butyl-4-(dimethylamino)phenyl]-1-phosphaethyne (2c).} $\mathrm{C}_{17} \mathrm{H}_{26} \mathrm{NP}$, monoclinic, space group $P 2{ }_{1} / n(\# 14), a=10.230(4), b=11.190(6), c=14.989(5) \AA ⿻, \beta=$ 93.24(1) $)^{\circ}, V=1713(1) \AA^{3}, Z=4, D_{\text {calc }}=1.068 \mathrm{gcm}^{-1}, \mu(\mathrm{Mo} \mathrm{K} \alpha)=1.50 \mathrm{~cm}^{-1} . \quad 2446$ Unique reflections with $2 \theta \leq 50.0^{\circ}$ were collected at $203 \mathrm{~K}$. Of these 2176 with $I>2.0 \sigma(I)$ were used for $R 1$ 
calculation. The structure was solved by direct method. The non-hydrogen atoms were refined anisotropically. Hydrogen atoms were included but not refined. $\quad R 1=0.075, R=0.139, R_{\mathrm{w}}=$ 0.165. Crystallographic data have been deposited at the Cambridge Crystallographic Data Centre (No. CCDC-227150).

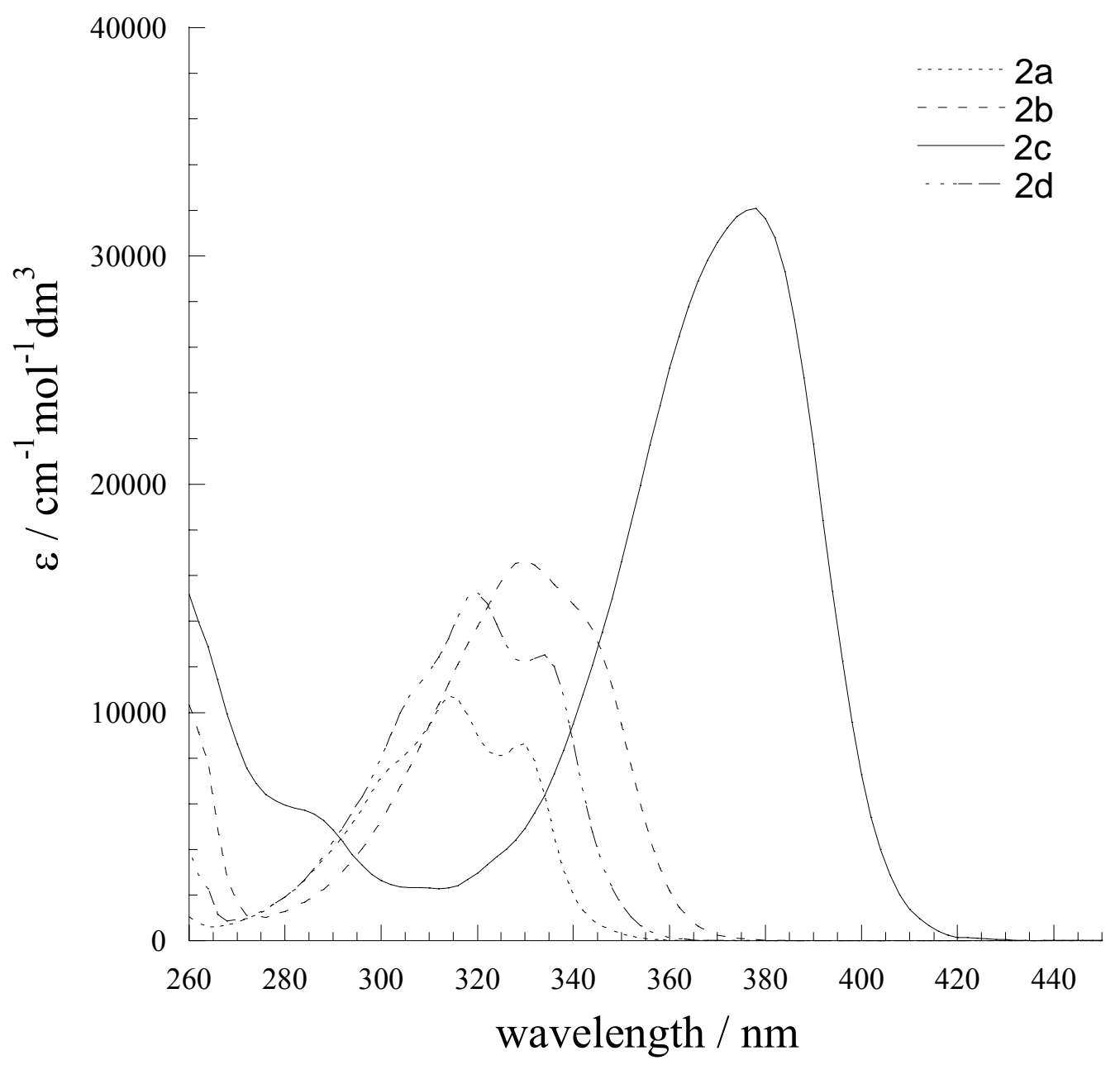

FIGURE 1. UV-vis spectra of $\mathbf{2 a - d}$ in $\mathrm{CH}_{2} \mathrm{Cl}_{2}$. 


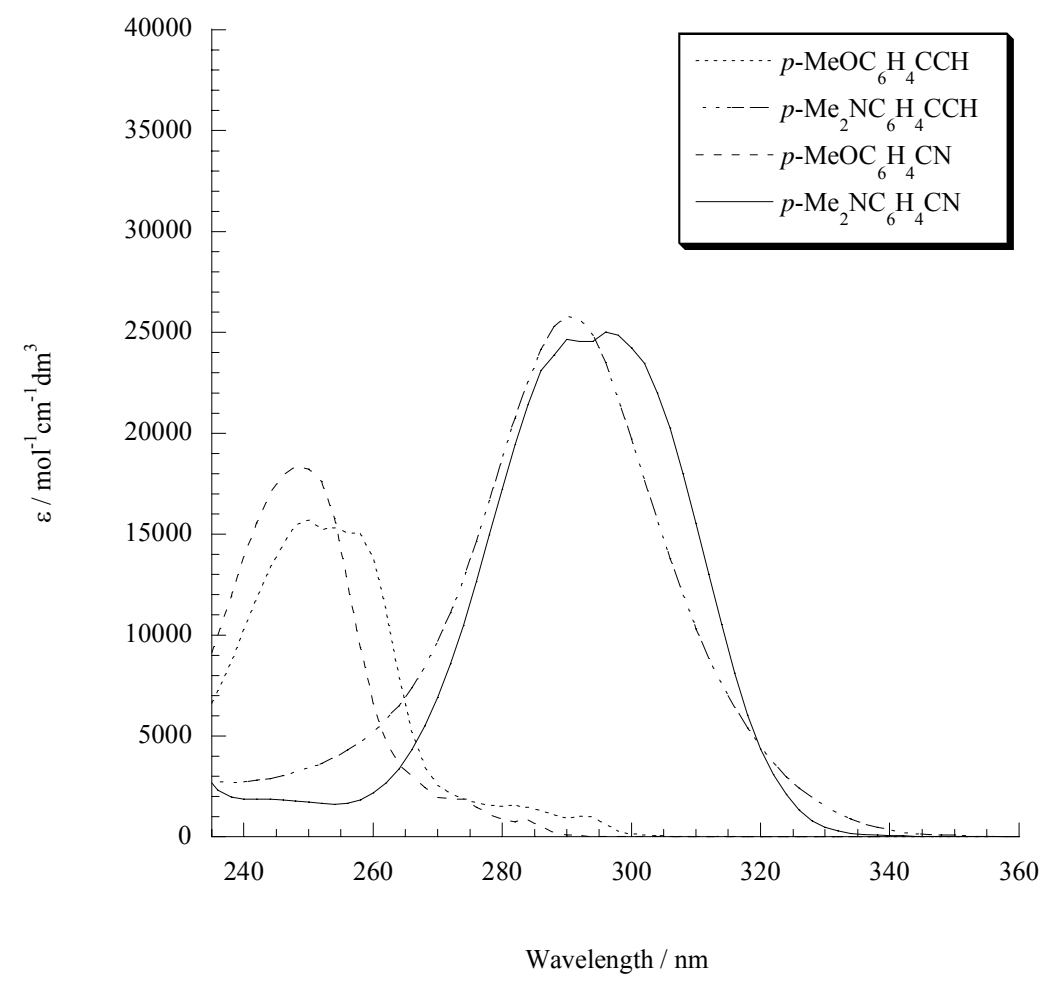

Figure 2. UV spectra of $p$-substituted phenylacetylenes and benzonitriles in $\mathrm{CH}_{2} \mathrm{Cl}_{2}$.

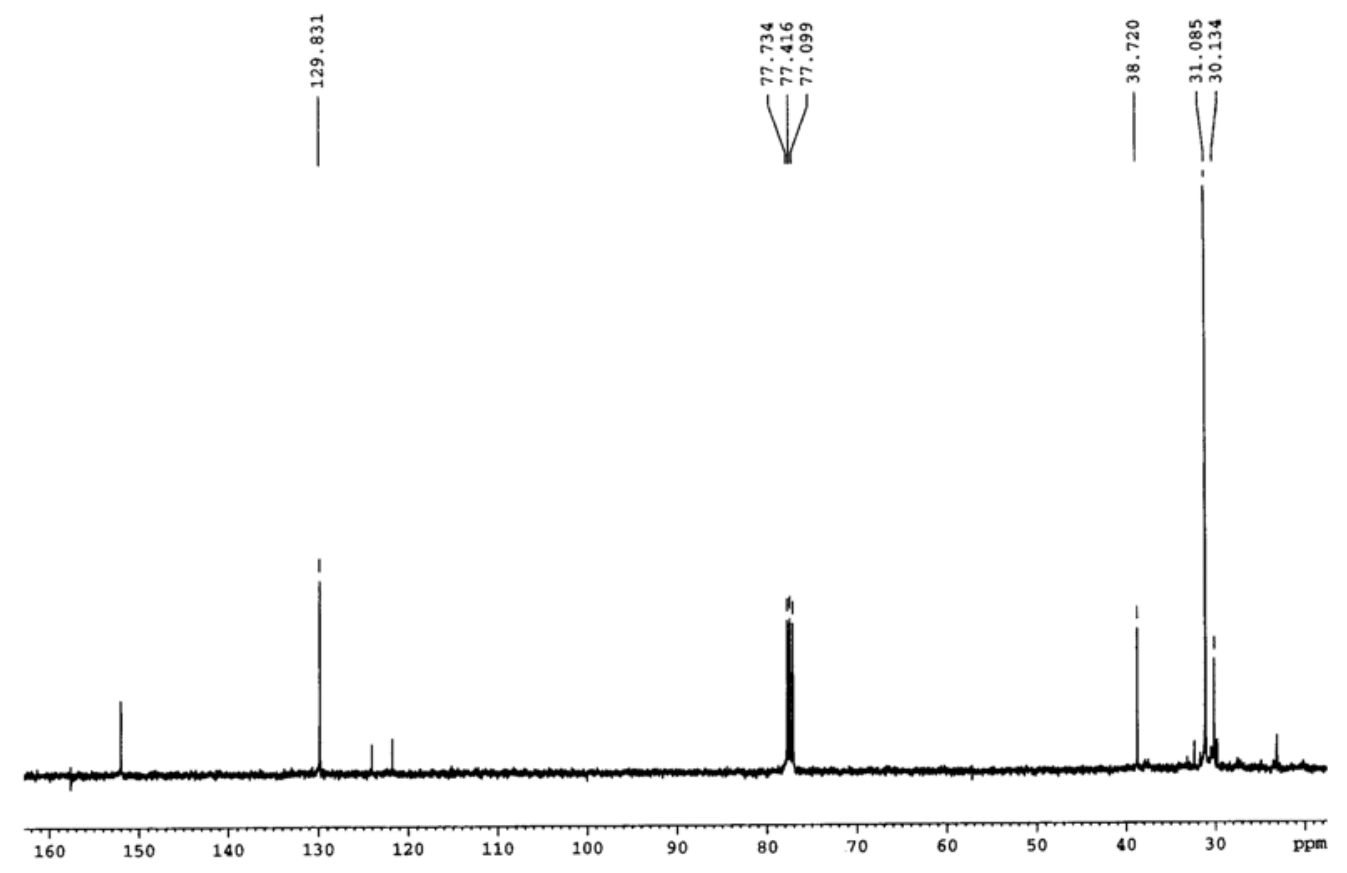

Figure 3. ${ }^{13} \mathrm{C}\left\{{ }^{1} \mathrm{H}\right\}$ NMR $\left(100 \mathrm{MHz}, \mathrm{CDCl}_{3}\right)$ spectrum of 2,5-dibromo-1,3-di-t-butylbenzene (1e). Trace of hexane was included in the spectrum. 


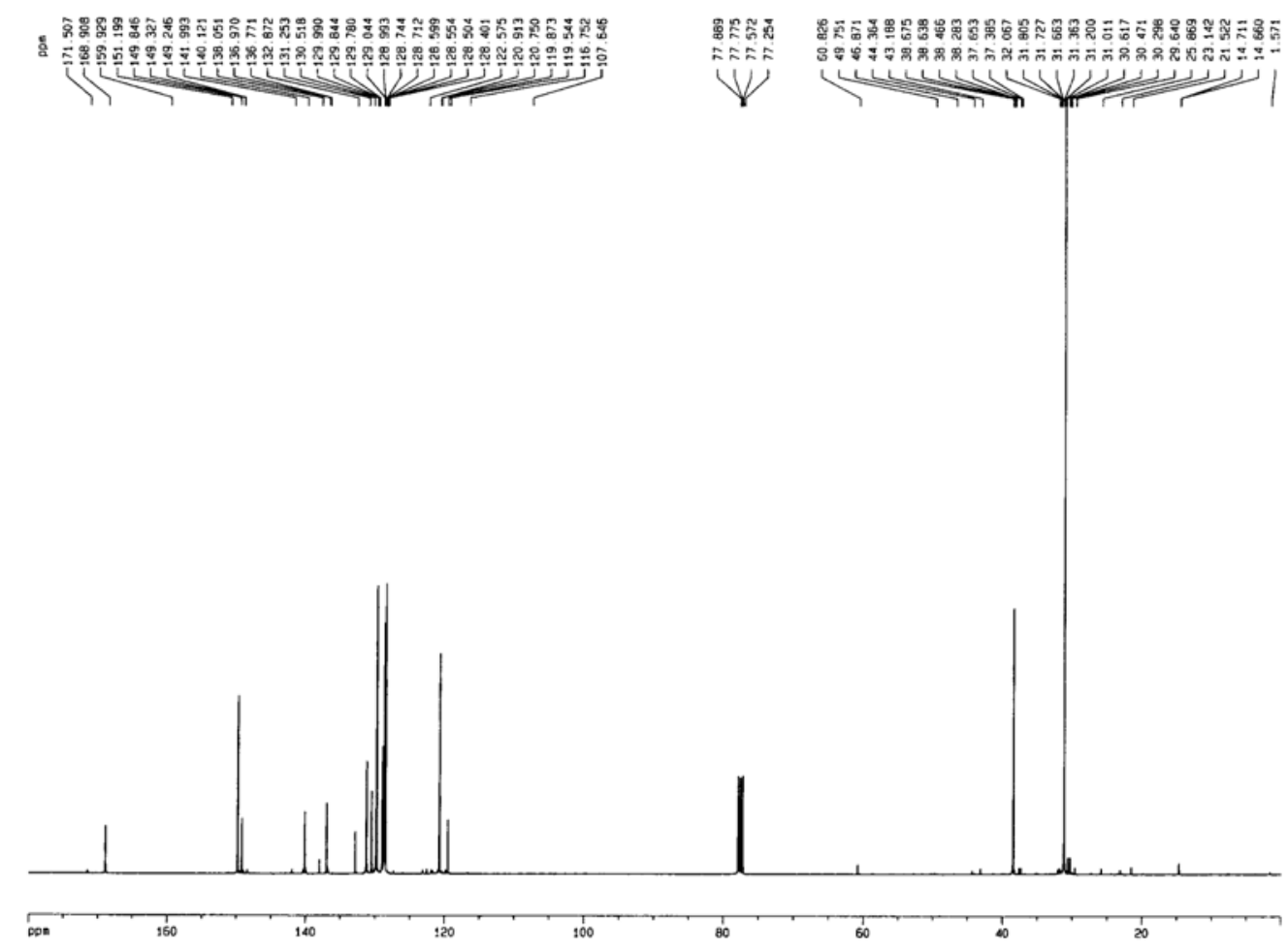

Figure 4. ${ }^{13} \mathrm{C}\left\{{ }^{1} \mathrm{H}\right\}$ NMR $\left(100 \mathrm{MHz}, \mathrm{CDCl}_{3}\right)$ spectrum of (4-bromo-3,5-di-t-butylphenyl)(diphenylmethylene)amine (1f).

ᄂ
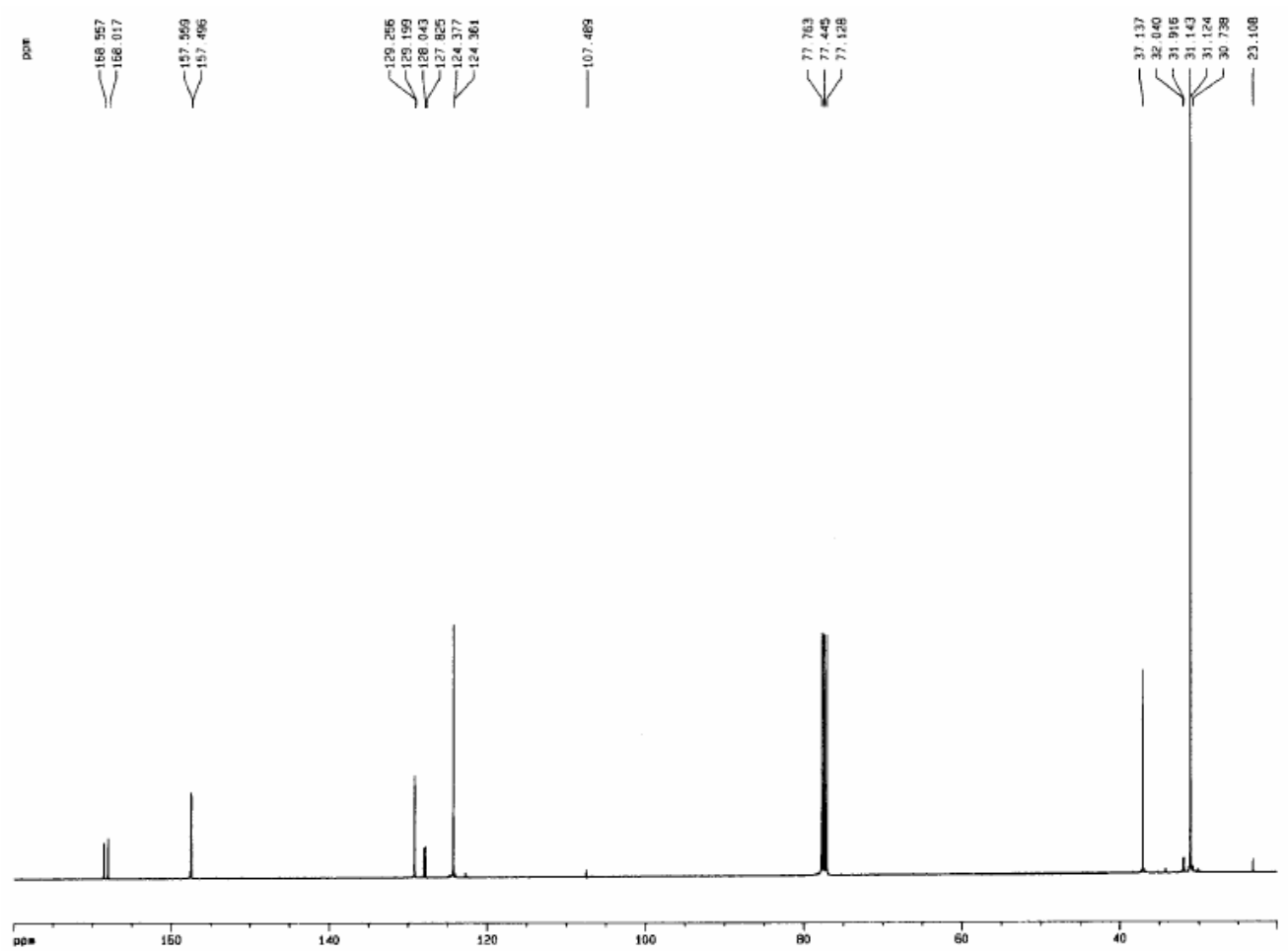

Figure 5. ${ }^{13} \mathrm{C}\left\{{ }^{1} \mathrm{H}\right\} \mathrm{NMR}\left(100 \mathrm{MHz}, \mathrm{CDCl}_{3}\right)$ spectrum of (2,6-di-t-butylphenyl)-1-phosphaethyne (2a). 


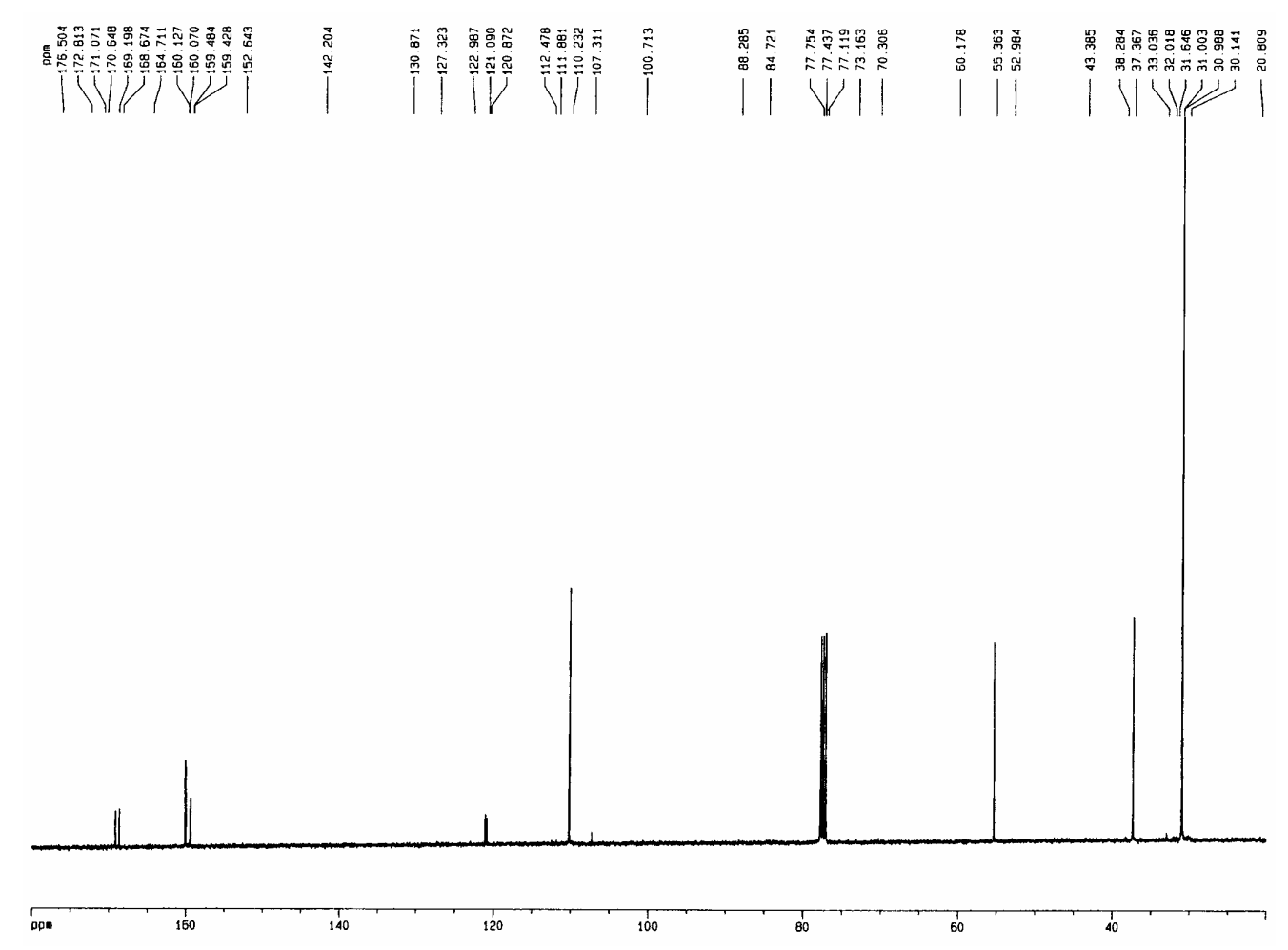

Figure 6. ${ }^{13} \mathrm{C}\left\{{ }^{1} \mathrm{H}\right\}$ NMR (100 MHz, $\left.\mathrm{CDCl}_{3}\right)$ spectrum of (2,6-di-t-butyl-4-methoxyphenyl)1-phosphaethyne (2b).

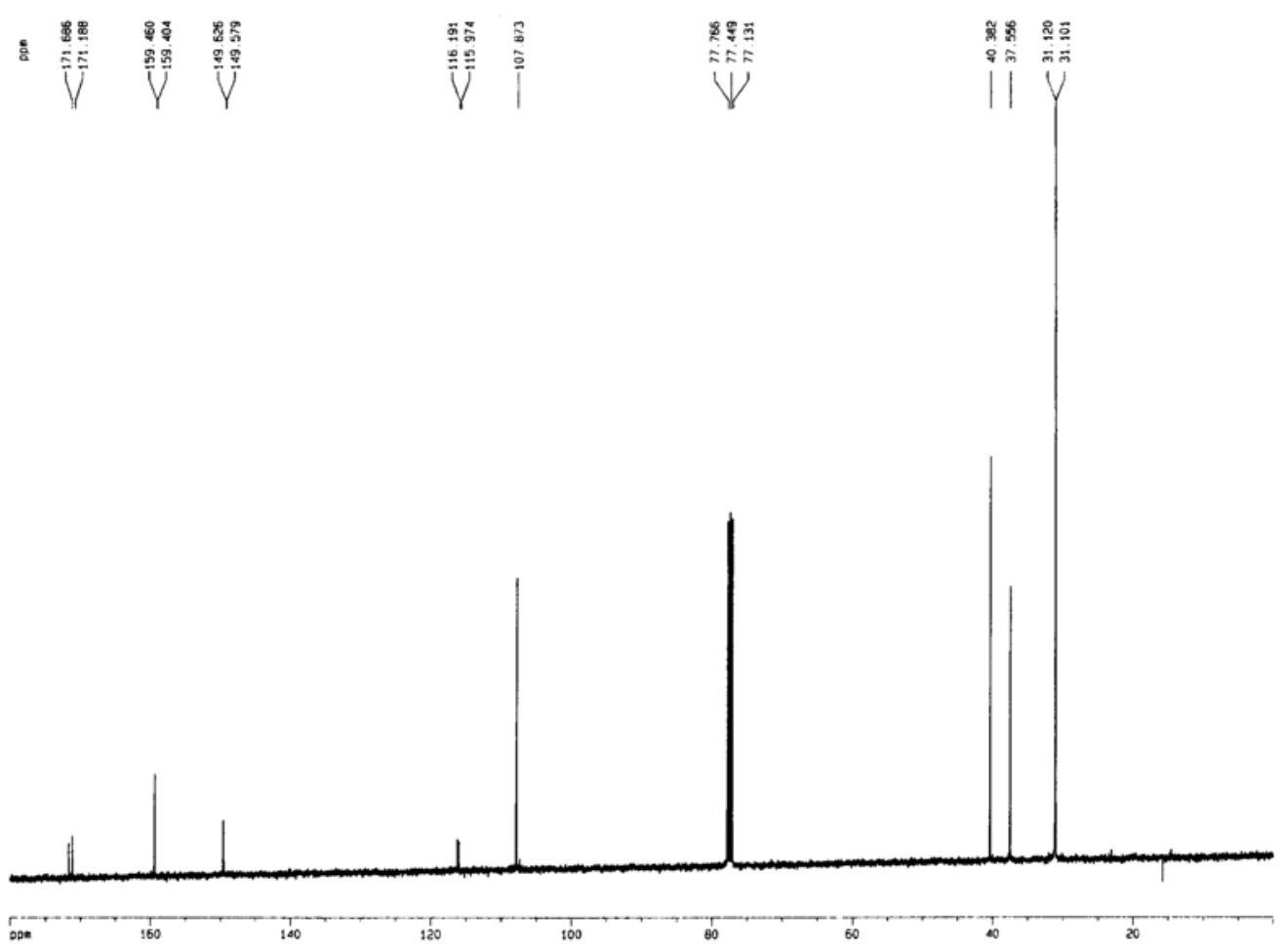

Figure 7. ${ }^{13} \mathrm{C}\left\{{ }^{1} \mathrm{H}\right\}$ NMR $\left(100 \mathrm{MHz}, \mathrm{CDCl}_{3}\right)$ spectrum of [2,6-di-t-butyl-4-(dimethylamino)phenyl]1-phosphaethyne (2c). 


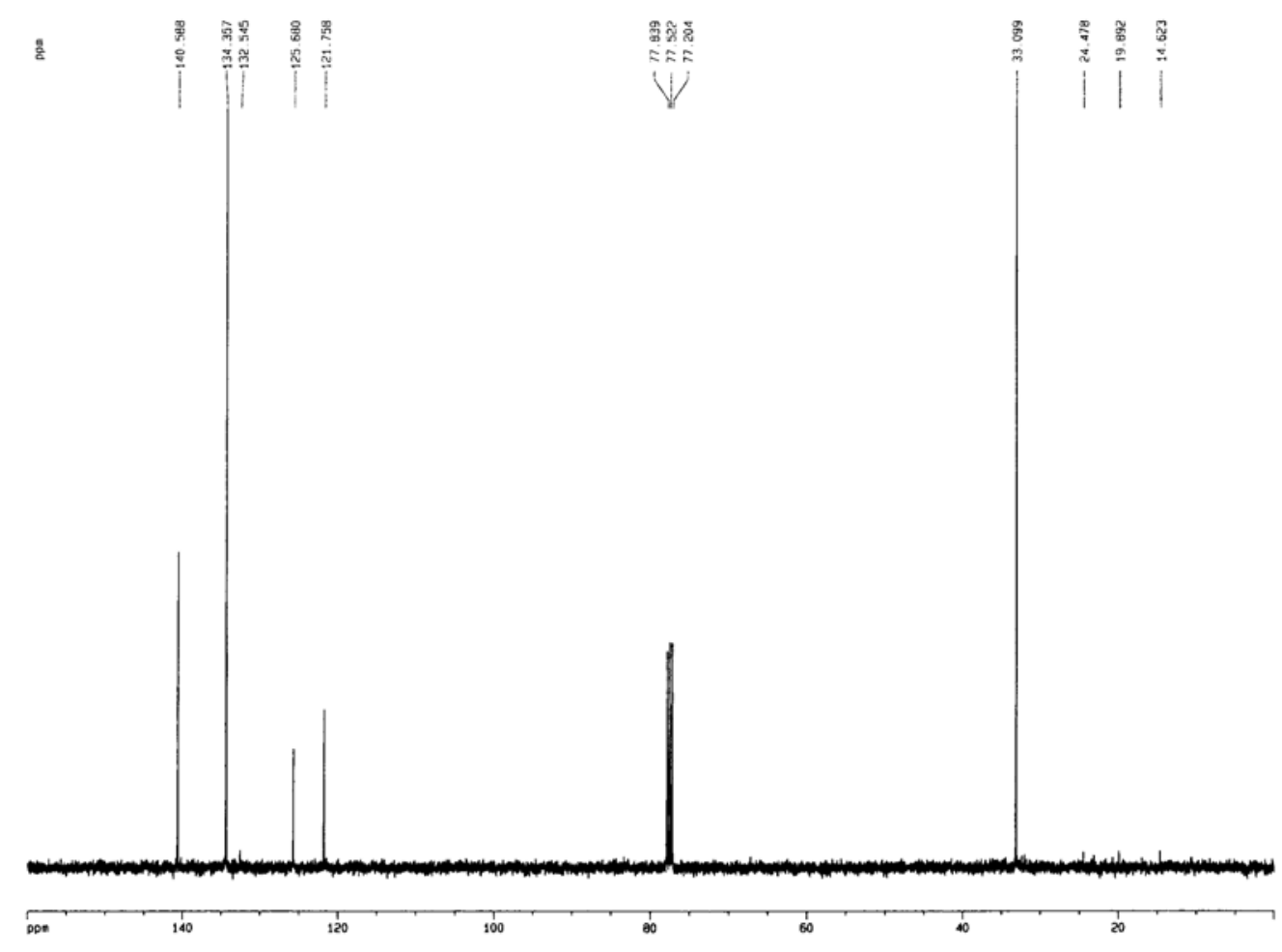

Figure 8. ${ }^{13} \mathrm{C}\left\{{ }^{1} \mathrm{H}\right\}$ NMR $\left(100 \mathrm{MHz}, \mathrm{CDCl}_{3}\right)$ spectrum of 2,5-dibromo-1,3-bis(bromomethyl)benzene (4).

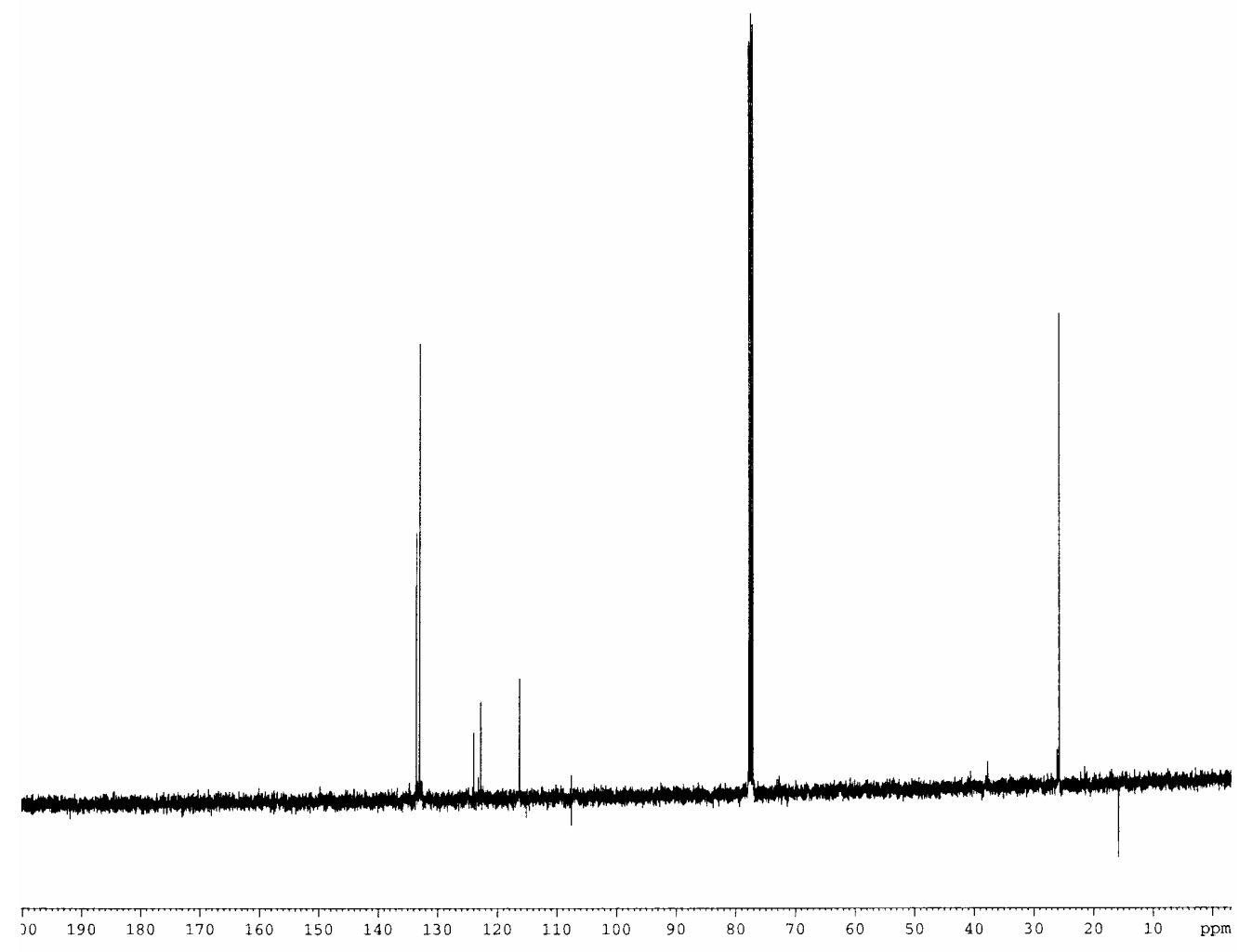

Figure 9. ${ }^{13} \mathrm{C}\left\{{ }^{1} \mathrm{H}\right\}$ NMR $\left(100 \mathrm{MHz}, \mathrm{CDCl}_{3}\right)$ spectrum of 2,5-dibromo-1,3-bis(cyanomethyl)benzene (5). 


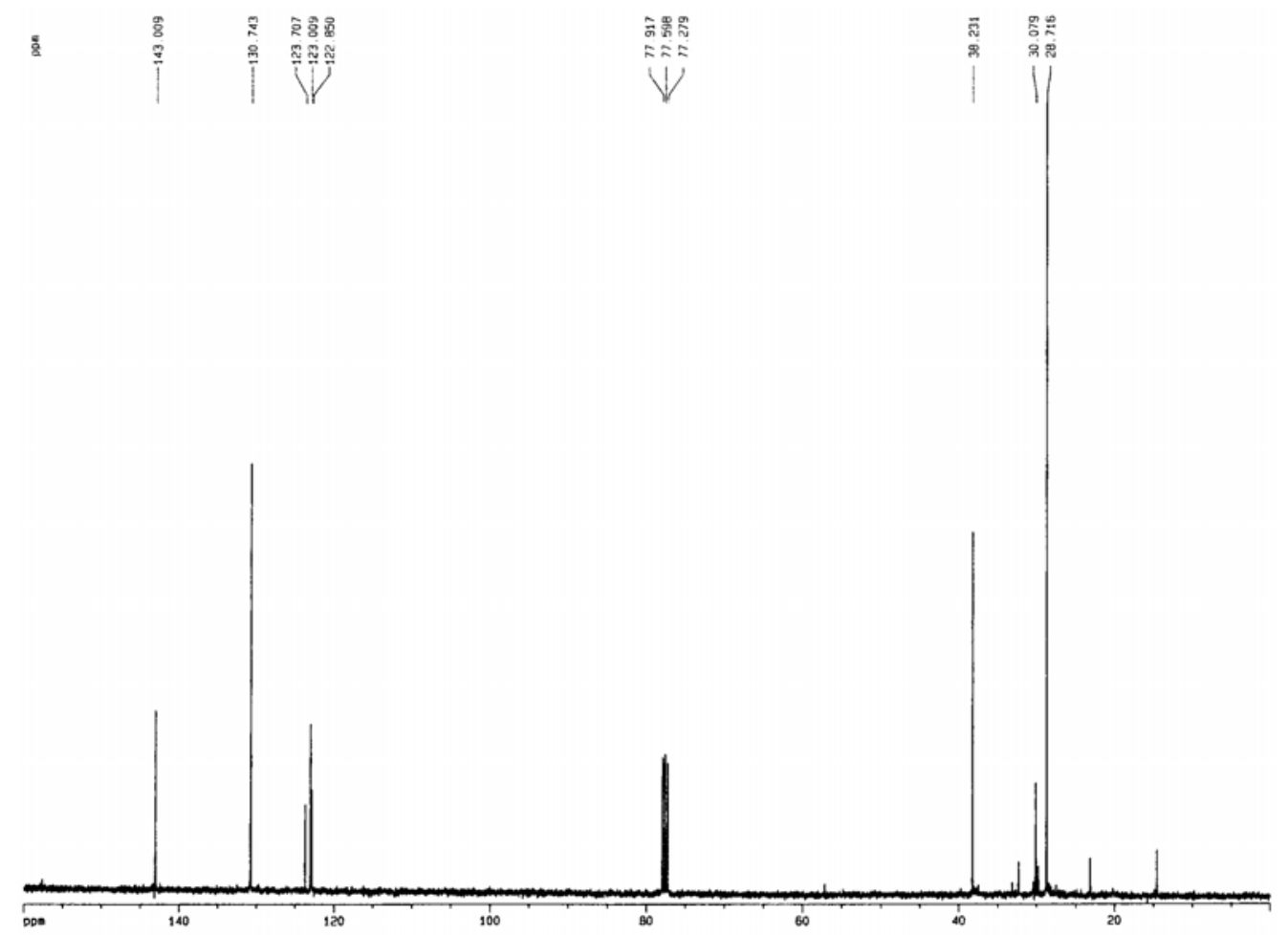

Figure 10. ${ }^{13} \mathrm{C}\left\{{ }^{1} \mathrm{H}\right\}$ NMR $\left(100 \mathrm{MHz}, \mathrm{CDCl}_{3}\right)$ spectrum of 2,5-dibromo-1,3-bis(1-cyano-1methylethyl)benzene (6). Trace of hexane was included in the spectrum.

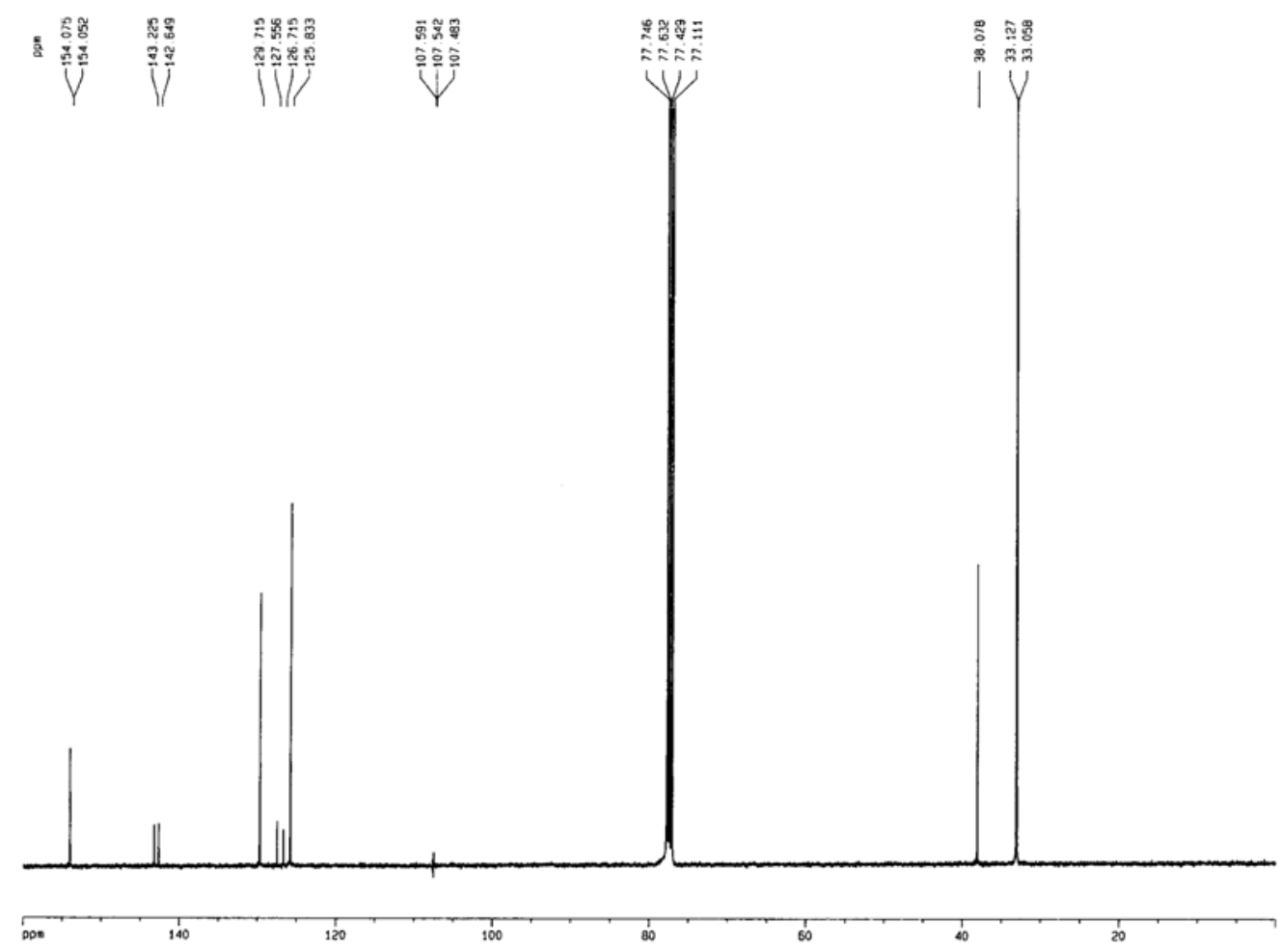

Figure 11. ${ }^{13} \mathrm{C}\left\{{ }^{1} \mathrm{H}\right\}$ NMR (100 MHz, $\mathrm{CDCl}_{3}$ ) spectrum of (dibromomethylene)(2,6-di-t-butylphenyl)phosphine (9a). 

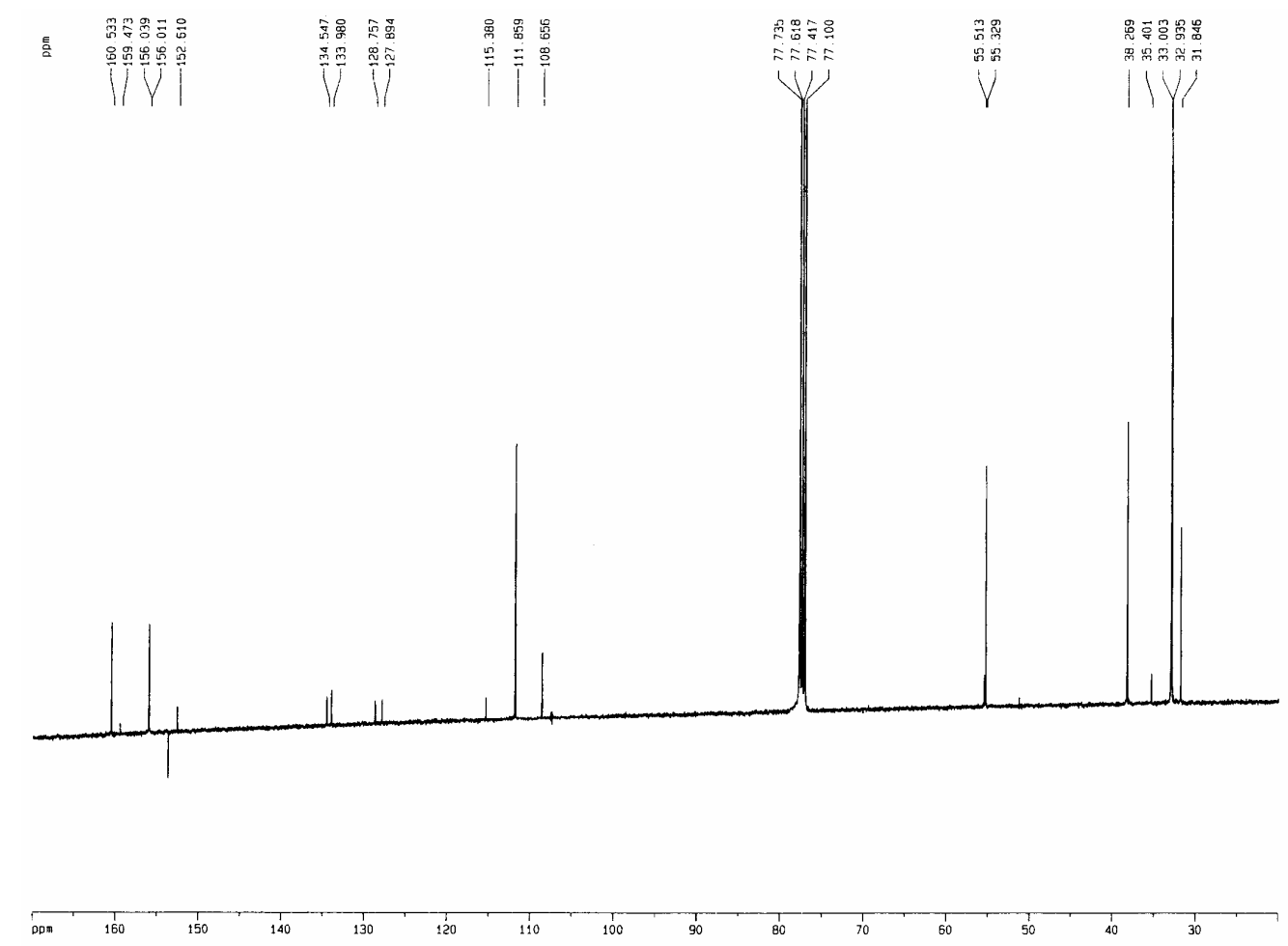

Figure 12. ${ }^{13} \mathrm{C}\left\{{ }^{1} \mathrm{H}\right\}$ NMR $\left(100 \mathrm{MHz}, \mathrm{CDCl}_{3}\right)$ spectrum of (dibromomethylene)(2,6-di-t-butyl-4methoxyphenyl)phosphine (9b). Partial decomposition of $9 \mathbf{b}$ occurred during the measurement. 